\title{
ATVIRO TIPO AKIŲ TRAUMOS: CHARAKTERISTIKOS IR PROGNOSTINIAI VEIKSNIAI
}

\author{
Justina Skruodytė ${ }^{1,2}$, Jūratẻ Sveikatienè ${ }^{2}$, Pranas Šerpytis $\breve{1}^{1,3,4}$ \\ ${ }^{1}$ Respublikinè Vilniaus universitetine ligonine, Skubios pagalbos skyrius, \\ ${ }^{2}$ Respublikine Vilniaus universitetine ligonine, Akiu ligu skyrius, ${ }^{3}$ Vilniaus universiteto \\ Medicinos fakulteto Klinikinès medicinos institutas, ${ }^{4}$ Vilniaus universiteto ligonine \\ Santaros klinikos, Skubios medicinos klinika
}

Raktažodžiai: akių trauma, atviro tipo traumos, akių sužalojimai.
Santrauka
Akių traumos yra viena iš pagrindinių ilgalaikius re- gèjimo sutrikimus sukeliančių priežasčių. Atviro tipo trauma apibrèžiama kaip viso storio akies sienos pažei- dimas, kuri gali sukelti ir aštrus, ir bukas mechanizmas. Akių traumos sudaro apie 44 proc. akių sužalojimų. Ty- rimo tikslas - atlikti naujausių mokslinių straipsnių de- talią literatūros apžvalgą apie atviro tipo akių traumas, išanalizuoti duomenis apie akių traumų paplitimo dažnį, etiologiją, epidemiologiją, klasifikaciją, nustatyti atviro tipo akių traumų klinikinius ypatumus ir gydymo baigtis. Nustatyta, kad dažniausiai atviro tipo traumas patiria dar- bingo amžiaus vyrai, kurie neturi akių apsaugos priemo- nių. Blogos regos prognostiniai veiksniai - pradinis RA $\leq 0,1$, teigiamas santykinis aferentinis vyzdžio defektas (RAVD), pradinè tinklainès atšoka, rainelès ar tinklainès prolapsas, stiklakūnio kraujosruva, ilgas laiko tarpas iki pradinès operacijos ir intervencinių procedūrų skaičius. Atviro tipo traumu gydymas beveik visais atvejais yra chirurginis, o chirurginių intervencijų planavimas ir jų skaičius priklauso nuo traumos sunkumo. Gydymo tikslas yra atkurti akies obuolio anatomiją ir pašalinti intraoku- linius svetimkūnius.
Sunkios akių traumos turi didelị socialinị ir ekonomini poveikị žmogui ir visuomenei. Traumą patyręs žmogus susiduria su psichologinèmis problemomis, pablogè- jusia gyvenimo kokybe, fizine negalia. Greita traumos diagnozè ir laiku pradètas chirurginis gydymas yra itin svarbūs, norint pagerinti regejjimo rezultatus, siekiant išvengti galimų komplikacijų.

\section{İvadas}

Akys sudaro tik 0,27 proc. viso kūno paviršiaus ploto, tačiau jos yra vienos iš dažniausiai traumų paveikiamų organizmo sričių [1]. Akių traumos viena dažniausių monokulinio aklumo priežasčių pasaulyje [2]. Akių sužalojimai sudaro apie 10 proc. visų pacientų, kurie kreipiasi ị skubiosios pagalbos klinikas [3]. Pasaulio sveikatos organizacija (PSO) apskaičiavo, kad kiekvienais metais pasaulyje įvyksta 55 mln. akių traumų, dèl akių sužalojimo regèjimo netenka apie $1,6 \mathrm{mln}$. žmonių, silpnaregiais abiem akimis tampa $2,3 \mathrm{mln}$. žmonių [2]. Regèjimo praradimas ženkliai paveikia visas gyvenimo sritis [4-6].

Akių traumų žala visuomenei ir sveikatos apsaugos sistemai yra ypač didelè. Kasmetinès hospitalizuotų pacientų dèl akių pažeidimų gydymo išlaidos Australijoje yra 155 milijonai JAV dolerių, o Jungtinèse Amerikos Valstijose 200 milijonų JAV doleriu [3], tiesioginès išlaidos susijusios su gydymu, chirurgine intervencija ir hospitalizacijos poreikiu, netiesioginès - prarastos darbo dienos, pablogèjusi gyvenimo kokybė bei psichologinès problemos [7]. Išsami akių sužalojimų epidemiologinių, etiologinių veiksnių ir jų baigčių analizė yra reikšminga priemonè, norint tinkamai ir efektyviai valdyti akių traumas, siekiant išvengti negrižtamo regos praradimo. Greita diagnozė ir laiku pradètas chirurginis pažeistos akies anatomijos atkūrimas yra itin svarbūs, norint pagerinti regejjimo rezultatus, siekiant išvengti galimu komplikacijų [8].

Tyrimo tikslas - atlikti naujausių mokslinių straipsnių detalią literatūros apžvalgą apie atviro tipo akių traumas. Išanalizuoti duomenis apie akių traumų paplitimo dažnị, etiologiją, epidemiologiją, klasifikaciją, nustatyti atviro tipo akių traumų klinikinius ypatumus ir gydymo baigtis. 


\section{Tyrimo medžiaga ir metodai}

Mokslinių straipsnių, kurie nagrinèja atviro tipo akių traumų ypatumus, paieška atlikta PubMed duomenų bazèje. Analizès metu apžvelgta 20 straipsnių. Naudoti raktiniai žodžiai: akių traumos ir sužalojimai, atviro tipo akių trauma.

\section{Tyrimo rezultatai}

Nepaisant medicinos pažangos išsaugoti ir atkurti regèjimą, akių traumos išlieka pagrindinè ilgalaikius regèjimo sutrikimus sukelianti priežastis $[1-3,6,7,9,10]$ ir gali lemti iki 65 proc. monokulinio aklumo atvejų visame pasaulyje [4]. Išsivysčiusiose šalyse akių traumų sukeliamas aklumas yra 9/100 000 gyventojų per metus, besivystančiose šalyse šis rodiklis dar aukštesnis ir siekia 75/100 000 [2].

Birmingemo akių traumų terminologija (BETT) - standartizuota akių traumų klasifikacijos sistema [4]. Pagal BETT, akių traumos būna atviro ir uždaro tipo, atsižvelgiant ị akies sienos būklę. Atviro tipo trauma (ATT) apibrěžiama kaip viso storio akies sienos pažeidimas (visiškas odenos, ragenos ar abiejų sužalojimas), kuri gali sukelti aštrios ar bukos traumos mechanizmas, neatsižvelgiant ị traumos mastą ar esamą regos aštrumą (RA) $[4,5,8,11,12]$. ATT sudaro apie 44 proc. visų akių sužalojimų, iš kurių apie 16-21 proc. diagnozuojamas intraokulinis svetimkūnis [2,4]. Lietuvos sveikatos mokslų universiteto Kauno klinikų (LSMU KK) Akių ligų klinikoje atlikto tyrimo duomenimis, žaizdos su intraokuliniais svetimkūniais sudare 40 proc. sužalojimų [13]. ATT yra viena iš pagrindiniųveiksnių, sukeliančių ịgytą regèjimo negalią ir vèlesnị gyvenimo kokybès blogejjimą [11]. Vidutinis apskaičiuotas ATT dažnis yra 3,5 atvejo 100000 gyventojų per metus, o tai sudaro 200000 atvejų per metus visame pasaulyje $[3,4,6,9,11]$. Abiejų akių pažeidimas nustatomas apie 7,54-22 proc. atvejų [6]. ATT, palyginti su bukomis traumomis, yra sunkesnès, siejamos su daugiau komplikacijų, didesniu chirurginių procedūrų poreikiu, ilgesniu gydymo laikotarpiu ir blogesnèmis prognozèmis [2].

Pagrindiniai odenos (skleros) plyšimo požymiai yra blogas RA (šviesos jutimas ar jo nèra), junginès chemozé ir kraujosruva, hifema, hipotonija, lęšiuko pažeidimas ar panirimas, stiklakūnio kraujosruva (hemoftalmas), tinklainès atšoka [9].

Remiantis BETT ir mechaninių akies sužalojimų klasifikacija, buvo pasiūlyta ir ịdiegta regos gydymo baigčių prognozavimo sistema - OTS (angl. ocular trauma score). Akiu traumų gydymo baigčių vertinimo sistemą (OTS) pasiūlè F. Kuhn ir bendraautoriai, kurie išanalizavo JAV Akių traumų registro (USEIR) duomenis, siekdami nustatyti specifinius prognostinius veiksnius. Analizès metu buvo vertintas pradinis RA, akies obuolio plyšimų, endoftalmitų, perforuojančių žaizdų, tinklainès atšokų ir teigiamo santykinio aferentinio vyzdžio defekto (RAVD) skaičius. Vertinimai suskirstyti ị penkias kategorijas, kurios naudojamos akių traumų baigčių prognozavimui $[1,5,6,14]$.

Didžiausia akių traumos rizika nustatyta darbingo amžiaus vyrams $[1,6,7,14]$. Vyrai dažniau dirba pavojingesnèje aplinkoje, dažniau patiria smurtinių traumų [7]. ATT dažnis vyrams siekia net $64,0-79,5$ procento $[15,16]$. Respublikinejje Vilniaus universitetinèje ligoninèje (RVUL) vyrai sudaro apie 85 proc. pacientų, kurie kreipiasi dèl akių sužalojimų. Remiantis retrospektyviu LSMU KK tyrimu, daugiau nei 70 proc. tiriamujų buvo darbingo amžiaus. Didžioji jų dalis - vyriškos lyties asmenys [13]. Dauguma žmonių traumą patiria 21-50 metų amžiaus grupejje $[14,16]$. Traumų etiologija keičiasi: jei XX a. daugiausia traumų ịvykdavo darbe, šiuo metu sparčiai didejja akių pažeidimų ne darbo metu (eismo įvykiuose, sportuojant, smurtaujant) [17]. Lietuvoje RVUL atlikto tyrimo duomenimis, apie 90 proc. traumų ivyksta buityje ir tik apie 10 proc. - darbe. Tai patvirtina G. Valaišaitès ir E. Puodžiuvienès $2019 \mathrm{~m}$. atlikto tyrimo duomenys: 88,2 proc. traumų ịvyko buityje, dažniausiai namuose, visose amžiaus grupese [13]. Su darbu susijusios akių traumos Kinijoje siekia net 56-72 procentus [2]. Nustatyta, kad žmonès, patiriantys ATT, dažniausiai neturi apsauginių priemonių [6]. Geresnis darbuotojų darbo saugos švietimas ir apsauginių akinių dèvejjimo užtikrinimas padètų sumažinti ATT dažnị [14].

Dažniausiai pasitaikančios akių sužalojimo priežastys - kelių eismo ịvykiai, sportiniai žaidimai ir laisvalaikio užsiëmimai, atitinkamai 32,7; 25,5 ir 20 procentų [2]. Automobilių oro pagalvių naudojimas susijęs su statistiškai reikšmingai padidėjusia akių traumų rizika, o saugos diržų naudojimas mažina akių traumų riziką [17]. Dažniausi ATT mechanizmai: $20-48$ proc. aštrūs daiktai, $30-60$ proc. buka trauma, sukelianti akies obuolio plyšimą $[2,16]$. Pavojingi akiduobės sienos lūžiai, nes smulkios jų nuolaužos gali sukelti kiaurini akies obuolio pažeidimą [2].

Dažniausia žaizdos lokalizacija - ragena. Atliktuose tyrimuose nustatyta, kad apie 12 proc. vyresnių nei 70 metų pacientų diagnozuojami veido ir akiduobès lūžiai, šiems pacientams 8,5 karto didesné tikimybé, kad jie dèl patirtos traumos bus hospitalizuoti [7].

Nors akių sužalojimų skaičiai bėgant metams mažèjo arba išliko stabilūs, JAV ir toliau daugèja su kritimais susijęs ATT skaičius. $2006 \mathrm{~m}$. kritimai sudare 7,5 proc. ATT, o 2014 m.- 10,9 proc., tai reiškia 45 proc. padidejjimą per 9 metų laikotarpi. Australijoje kritimai sukelia 43 proc. ATT atvejų. Daugiausia su kritimais susijusių sužalojimų patiria vyresnio amžiaus žmonès (vidutinis amžius - 73 metai). Pasaulyje gyventojams senstant, oftalmologai turetų būti gerai pasirengę spręsti su kritimais susijusių akių traumų 
sukeltas problemas, kad ateityje būtų išvengta ATT [7].

Dažna akių traumų priežastis - žvejyba. Alfaro ir bendr. išanalizavo JAV akių sužalojimų registro (USEIR) duomenis, kuriuose pranešta, kad su žvejyba susiję akių sužalojimai sudare 19,54\% visų su sportu susijusių akių traumų [18]. Dauguma ATT ịvyksta vasaros mėnesiais, tai galima paaiškinti padidejusia veikla lauke [7].

Remiantis literatūros apžvalga, blogos regos prognostiniai veiksniai - pradinis $R A \leq 0,1$, RAVD buvimas, pradinè tinklainès atšoka, rainelès ar tinklainès prolapsas, stiklakūnio kraujosruva (hemoftalmas), pradinès operacijos atidejjimas ir chirurginių intervencijų skaičius $[1,2,5,9,14]$. Skubus, ankstyvas ir tinkamas oftalmologinis icvertinimas yra galimybe tinkamai valdyti akies traumas, tačiau dèl aplinkinių periorbitalinių minkštųų audinių edemos, kraujosruvų, ištyrimas gali būti apsunkintas [2], todèl vaizdiniai radiologiniai tyrimai yra būtini, norint nustatyti akies obuolio sužalojimo mastą ir pradèti tinkamą gydymą [2,8]. ATT atvejais informatyvūs kompiuterinès tomografijos (KT), ultragarsinès biomikroskopijos (UG) ir magnetinio rezonanso tomografijos (MRT) tyrimai. KT pasižymi dideliu jautrumu $(\leq 90 \%)$ intraorbitaliniams ar intraokuliniams svetimkūniams. KT trūkumai: dèl metalinių svetimkūnių galimi artefaktai. UG - pagalbinis metodas, galintis padèti diagnozuoti hifemą, lęšiuko panirimą, akies obuolio plyšimą, intraokulinius svetimkūnius, hemoftalmą ar tinklainès atšoką [2]. Optinès koherentinès tomografijos (OKT) tyrimo metu galima įvertinti užpakalini akies segmentą. ATT gydymas beveik visais atvejais yra chirurginis, o chirurginių intervencijų planavimas ir jų skaičius priklauso nuo traumos sunkumo.

Pagrindinis ATT chirurginio gydymo tikslas yra atkurti akies obuolio anatomiją ir pašalinti intraokulinius svetimkūnius [2].

Gydymo sèkmé priklauso nuo pirminio akies obuolio vientisumo atkūrimo ir empirinès antibiotikoterapijos $[2,6]$. Laikas nuo traumos iki gydymo pradžios labai svarbus, siekiant sumažinti komplikacijų dažnį.

Apie 70 proc. pacientų laiku kreipiasi ị gydymo ịstaigą [14]. 62,1-89 proc. pacientu pirmoji operacija atliekama per pirmąsias 24 valandas po sužalojimo [6]. Lietuvoje atlikto tyrimo metu nustatyta, kad apie 60 proc. tiriamujų i gydymo ịstaigą kreipési per pirmąsias 24 valandas, beveik visiems iš jų atlikta pradinè chirurginè intervencija per tą patị laiko tarpą [13]. RVUL atlikto tyrimo duomenimis, 77,3 proc. tiriamujų atvyko i gydymo ịstaigą traumos dieną, 17,5 proc. - iki 3 paros po traumos, 5,3 proc. - vèliau nei 3 parą. Enukliacijos (akies obuolio pašalinimo operacija) dažnis po ATT svyruoja nuo 7 iki 31,8 procento [5].

Akių traumų vitrektomijos studija EIVS (angl. Eye injury vitrectomy study) pabrěžia, kad 25 proc. atvejų po ATT, akies obuoli galima išsaugoti laiku atlikus pars plana vitrektomiją (PPV). Laiku atlikta PPV ženkliai sumažina enukleacijos ir infekcinio endoftalmito riziką [2]. PPV būtina atlikti esant ATT su jau esančia tinklainès atšoka ar diagnozavus intraokulinius svetimkūnius.

Profilaktiškai ị stiklakūnį antibiotikai turètų būti leidžiami tik tais atvejais, kai yra klinikinių infekcijos požymių arba didelè infekcijos rizika, sužalojimas organinès kilmès daiktais.

Endoftalmitas - viena sunkiausių ATT komplikacijų. Tarp pacientų, sergančių infekciniu endoftalmitu, potrauminis endoftalmitas sudaro 25-31 proc. atveju [19]. Pagrindiniai trauminio endoftalmito rizikos veiksniai: atidèta pradinè operacija, sužalojimai su intraokuliniais svetimkūniais, labai užteršta žaizda ir žemès ūkio traumos $[19,20]$. Nors nèra endoftalmito profilaktikos auksinio standarto gairių, rekomenduojamas vietinių, sisteminių ir intravitrealinių plataus veikimo spektro antibiotikų derinys. Priešgrybelinè profilaktika paprastai nerekomenduojama, jei nèra klinikinių ar mikrobiologinių grybelinės infekcijos požymių [19].

Kitos retos ir sunkios komplikacijos: simpatiné oftalmija (lètinis autoimuninis uveitas sveikojoje akyje), akies sunykimas (lot. phthisis bulbi), dažnai diagnozuojama antrinè glaukoma.

Sunkios akių traumos turi didelị socialinị ir ekonomini poveikị žmogui bei visuomenei. Traumą patyręs žmogus susiduria su psichologinèmis problemomis, pablogèjusia gyvenimo kokybe, fizine negalia, todèl reikšmingos akių traumų prevencijos programos, akių apsaugos priemoniu dèvejimas ir darbo saugos reikalavimų laikymasis.

\section{Išvados}

1. ATT dažnis yra nemažas. Nors taikoma efektyvi diagnostika ir gydymas pradedamas laiku, ATT gydymo baigtis dažniausiai nepalanki.

2. ATT reikšmingai dažniau patiria darbingo amžiaus vyrai, kurie neturi akių apsaugos priemonių.

3. Svarbu dèmesị skirti visuomenès švietimui, prevencijos programoms, nes dažniausiai akių traumų sukeliamų pažeidimų galima išvengti.

\section{Literatūra}

1. Yaşa D, Erdem ZG, Demircan A, Demir G, Alkın Z. Prognostic value of ocular trauma score for open globe injuries associated with metallic intraocular foreign bodies. BMC Ophthalmol 2018;18(1):194.

https://doi.org/10.1186/s12886-018-0874-3

2. Chen Z, Li SM. Trauma of the globe: state of art in global and in China. Chinese Journal of Traumatology 2016; 19(6): 317-318. https://doi.org/10.1016/j.cjtee.2016.11.001

3. AlMahmoud T, Al Hadhrami SM, Elhanan M, Alshamsi HN, 
Abu-Zidan FM. Epidemiology of eye injuries in a high-income developing country. Medicine (Baltimore) 2019; 98(26): e16083.

https://doi.org/10.1097/MD.0000000000016083

4. Fujikawa A, Mohamed YH, Kinoshita H, Matsumoto M, Uematsu M, Tsuiki E et al. Visual outcomes and prognostic factors in open-globe injuries. BMC Ophthalmol 2018;18(1):138. https://doi.org/10.1186/s12886-018-0804-4

5. Brundridge W, Reed D, Santamaria J, Mehta A, Valentin F, Davies B. Open globe trauma in a military hospital: a review of the ocular trauma score to help predict enucleation or evisceration. Graefes Arch Clin Exp Ophthalmol 2019; 257(8):1789-1793. https://doi.org/10.1007/s00417-019-04356-5

6. Guven S, Durukan AH, Erdurman C, Kucukevcilioglu M. Prognostic factors for open-globe inju-ries: variables for poor visual outcome. Eye (Lond) 2019; 33(3): 392-397.

https://doi.org/10.1038/s41433-018-0218-9

7. Mir TA, Canner JK, Zafar S, Srikumaran D, Friedman DS, Woreta FA. Characteristics of open globe injuries in the United States from 2006 to 2014. JAMA Ophthalmol 2020; 138(3):268-275. https://doi.org/10.1001/jamaophthalmol.2019.5823

8. Bodanapally UK, Addis H, Dreizin D, Reddy AK, Margo JA, Archer-Arroyo KL et al. Prognos-tic predictors of visual outcome in open globe injury: emphasis on facial CT findings. AJNR Am J Neuroradiol 2017; 38(5):1013-1018.

https://doi.org/10.3174/ajnr.A5107

9. Yucel OE, Demir S, Niyaz L, Sayin O, Gul A, Ariturk N. Clinical characteristics and prognostic factors of scleral rupture due to blunt ocular trauma. Eye (Lond) 2016; 30(12):1606-1613. https://doi.org/10.1038/eye.2016.194

10. Stryjewski TP, Andreoli CM, Eliott D. Retinal detachment after open globe injury. Ophthalmo-logy. 2014; 121(1):10.

https://doi.org/10.1016/j.ophtha.2013.06.045

11. Upaphong P, Supreeyathitikul P, Choovuthayakorn J. Open globe injuries related to traffic acci-dents: a retrospective study. Journal of Ophthalmology 2021; 2021: 6629589. https://doi.org/10.1155/2021/6629589

12. Makhrash MA, Gosadi IM. Open globe eye injury characteristics and prognostic factors in Ja-zan, Saudi Arabi. Saudi Med J 2016; 37(12):1328-1333.

https://doi.org/10.15537/smj.2016.12.15545

13. Valaišaitė G., Puodžiuvienè E. Atviro tipo akių traumų klinikinių ypatumų ir išeičių vertinimas. Baigiamasis magistrinis darbas: LSMU, 2019.

14. Meng Y, Yan H. Prognostic factors for open globe injuries and correlation of ocular trauma sco-re in Tianjin, China. Journal of Ophthalmology 2015; 2015: 345764.

https://doi.org/10.1155/2015/345764

15. Batur M, Seven E, Esmer O, Akaltun MN, Yasar T, Cinal A. Epidemiology of adult open globe injury. J Craniofac Surg 2016; 27(7):1636-1641.
https://doi.org/10.1097/SCS.0000000000003001

16. Orr CK, Bauza A, Langer PD, Zarbin MA, Bhagat N. Openglobe injuries with motor vehicle accidents: a 12-year review. Graefes Arch Clin Exp Ophthalmol 2015; 253(8):1313-7. https://doi.org/10.1007/s00417-015-2929-y

17. Puožiuvienė E. Sunkių akių traumų ypatumai ir regos reabilitacijos iqvertinimas. Daktaro disertacija. KMU, 2008.

18. Purtskhvanidze K, Saeger M, Treumer F, Nölle B, Roider J. Open globe and penetrating eyelid injuries from fish hooks. BMC Ophthalmology 2019;19: 26. https://doi.org/10.1186/s12886-019-1040-2

19. Ahmed Y, Schimel AM, Pathengay A, Colyer MH, Flynn Jr HW. Endophthalmitis following open-globe injuries. Eye (Lond) 2012; 26(2): 212-217. https://doi.org/10.1038/eye.2011.313

20. Chehab HE, Renard JP, Dot C. Post-traumatic endophthalmitis. J Fr Ophtalmol 2016; 39(1):98-106. https://doi.org/10.1016/j.jfo.2015.08.005

\section{OPEN GLOBE EYE INJURY: CHARACTERISTICS AND PROGNOSTIC FACTORS}

J. Skruodytė, J. Sveikatienė, P. Šerpytis

Keywords: ocular trauma, open global injury, traumatic eye injury.

Summary

Ocular trauma (Ocular injury) is the leading cause of unilateral blindness worldwide, especially in the developing countries. Among ocular traumas, the open globe injury is the most common one and account for $44 \%$ of all eye injuries. They are defined by the damage to the entire thickness of the eye wall and are caused by both acute and blunt trauma mechanisms The most affected people's group by eye injuries are working-age men. It has been found that people who experience open globe injuries usually do not follow safety requirements at work and rarely wear any eye protection.

The are a few major prognostic factors to recognize the damaged vision. For instance, initial visual acuity is lower or equal to 0,1 ; positive relative afferent pupillary defect (RAPD), initial retinal detachment, prolapsed tissue, vitreous hemorrhage, and ,finally, the time of the initial operation as well as the number of operational procedures. The treatment of open globe injury in almost all cases is surgical: the planning and the number of surgical interventions depend on the severity of the injury. The goal of treatment is to restore the anatomy of the eyeball and to remove the intraocular foreign bodies.

Severe eye injuries have a significantly negative socio-economic impact on the individual as well as the whole society. A person who has suffered an injury often facespsychological problems, has a deteriorating quality of life and a physical disability. Rapid diagnosis of trauma and timely surgical restoration of the anatomy of the damaged eye are essential to improve patient's vision and avoid potential complications in the future.

Correspondence to: skruodytes@gmail.com

Gauta 2021-04-26 